\title{
CSR DISCLOSURE, PROFITABILITY AND SOLVENCY TOWARDS FIRM VALUE
}

\author{
Fatimah \\ fatimah_wmz@yahoo.com \\ Dadan Sukardan \\ Faculty of Economic and Business, Universitas Pasundan
}

diterima: 12/3/2018; direvisi: 6/7/2018; diterbitkan: 29/10/2018

\begin{abstract}
The Purpose of this research is to empirically examine the effect of CSR Disclosure, Profitability and Solvency towards Firm Value on Mining Company listed in Stock Exchange of each country in ASEAN in 2006-2013. The sampling method used in this research is purposive sampling with criteria of companies that issued their financial and CSR report during the period of 2006-2013. Data obtained from Stock Exchange of each country in ASEAN with the period of 2006 to 2013 and total population of 54 companies. Analysis techniques used in this research is multiple linear regression analysis and hypothesis testing used is partial test ( $t$ test) with a significance level of 5\% and coefficient of determination test. Statistical test results showed that CSR Disclosure, Profitability and Solvency have no significant effect towards Firm Value.
\end{abstract}

Keywords: CSR disclosure; profitability; solvency; firm value

\section{INTRODUCTION}

A good company should be able to control the financial and non-financial potential in improving the company's value for the existence of the company in the long term. Maximizing the value of a company is very important for a company, because by maximizing the value of a company also means to maximize shareholder's wealth that is the main goal of the company.

High stock prices make the value of the company is high too. High corporate value will make the market believe not only in the company's current performance, but also on the future prospects of the company. The value of the firm in this study is defined as market value, such as the research that was conducted by Agustina (2013) because the market value can provide maximum shareholder wealth if the stock price of the company increases. The higher the price, the higher the shareholder's wealth. In general, the investors hand over the management of corporate value to professionals such as managers or commissioners.

According to Brigham and Houston, 2011: 151 translated by Ali Akbar Yulianto, the stock market value can be shown through the comparison of the stock market price of the firm with the book value. If the market value of the company's stock is greater than the book value, then the value of the company can be cotegorised as good because the investors are willing to pay shares greater than the value of the accounting book.

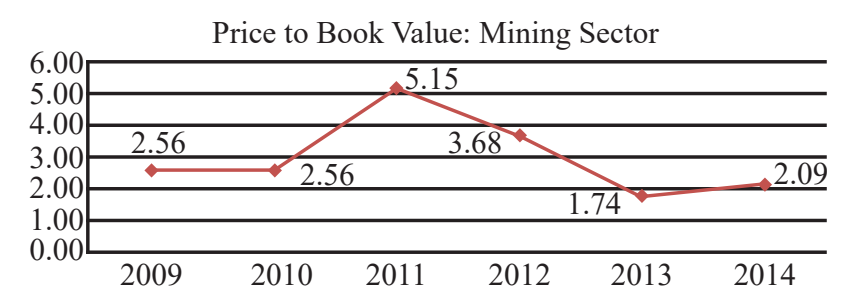

Source: IDX Statistics Book 2009-2012 (processed)

Figure 1. Graph of Firm Value of Mining Companies listed on IDX Year 2009 - 2014

Figure 1 shown that the company's value in the mining sector has dropped dramatically from its highest level in 2011 of 5.15 to 1.74 in 2013; below the PBV (Price to Book Value) position in 2009. In 2014, the value of mining sector companies rose by $20.12 \%$ to 2.09. The global economic conditions plus the industry's performance that grew negative made the market optimism for mining sector stocks to run low.

From an article written by Risa Herdahita Putri on August 6, 2015 in Republika.co.id, sound the middle of 2015, in Indonesia Stock Exchange (IDX), the stock performance in several industrial sectors showed a decline. Shares in the mining industry sector became one of the two worst performers on a calendar year (year to date), reaching minus 26.62\% until the close of stock sales yesterday, Wednesday, August 5, 2015. 
According to Samuel Securities analyst Lana Soelistianingsih, market pessimism is linked to economic slowdown, decreased in demand, as well as production indices until declining profit margins in the industrial sector take a share in the stock's performance in the sector. While the movement of shares in the mining sector is strongly affected by the performance of the mining industry, the mining industry is also highly dependent on global markets.

As for news from Sindonews.com written by Disfiyant Glienmourinsie on May 4, 2016, the Central Bureau of Statistics (CBS) noted that the low price of coal commodities caused the mining sector in quarter $\mathrm{I} / 2016$ to contract and the growth was minus.

Deputy of Balance Sheet and Statistical Analysis of CBS, Kecuk Suharyanto revealed that the sector that sold well in the $2000 \mathrm{~s}$ was minus $0.66 \%$. This is because demand for coal from importing countries fell quite sharply.

The Central Bureau of Statistics (CBS) estimates the price of coal commodities will not be stable in the second quarter of this year, so it will continue to experience further contraction. CBS affirms that coal prices in international markets are still low and demand in importing countries is still low.

Today many leaders base their company's performance on financial performance. Various financial aspects in the company have a significant effect on the value of the company, one of them is profitability ratio. Companies that can earn big profits can be said to have succeed or have a good financial performance. Conversely, if the profit obtained by the company is relatively small, it can be said the company is less successful or has a poor performance (Agustina, 2013).

For a company, maintaining and improving financial performance is a must so that shares still exist and remain in demand by investors. The financial statements published by the company are reflection of the company's financial performance. Financial information has a function as a means of information, management accountability tools to the owners of the company, the depiction of corporate success indicators and as a material consideration in decision making (Harahap, 2013). Various financial aspects within the company significantly influence the value of the company, one of which profitability ratio. In general, the higher the profitability, the better the position of the owner of the company, thus causing a good assessment of the investor to the company that can increase the stock price and the value of the company.

In addition, solvency (leverage) can also be associated with firm value. Solvency (leverage) is illustrated to see the extent to which the company's assets are financed by debt compared to their own capital (Weston and Copeland, 1992 in Sukirni, 2012). The increasing use of debt, reflected by a larger debt ratio, on equal earnings before interest and taxes (EBIT) will result in greater earnings per share. If earnings per share increases, it will have an impact on increasing stock prices, and an increase in stock prices will linearly increase the value of the company.

An entity in running its business can not be separated from the society and the surrounding environment, thus creating mutual relationships between communities and companies. The company needs a positive response from the community gained through what the company does to its stakeholders, including the community and the environment (Kamil and Herusetya, 2012).

Corporate Social Responsibility is a mechanism for an organization to voluntarily integrate environmental and social concerns into its operations and its interaction with stakeholders. Corporate Social Responsibility (CSR) Disclosure becomes one of the factors that affect the value of the company because it is one of the rationale underlying the business ethics of a company (Susanti, 2010).

According to Yuniasih and Wirakusuma (2007), accountability can be met, and information asymmetry can be reduced if companies report and disclose their CSR activities to stakeholders. With CSR reporting and disclosure, stakeholders will be able to evaluate how CSR is implemented. The more companies disclose CSR in the annual report, the better the value of the company in the eyes of investors, creditors, or the public.

The purpose of this study is to find out how much is the influence of CSR Disclosure, Profitability, and Solvency on Firm Value partially with the research paradigm shown in Figure 2

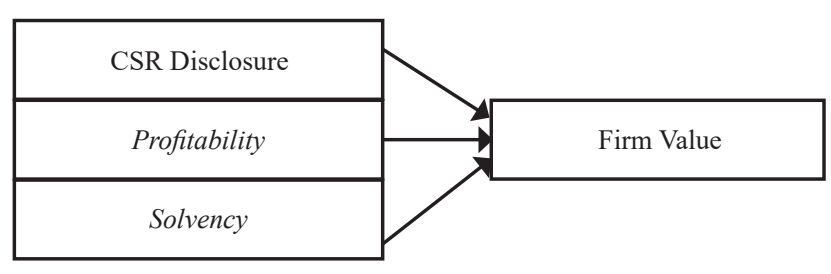

Figure 2. Research Paradigm

Based on the formulation of problem and framework, the research hypotheses are formulated as follow: (a) CSR Disclosure influences Firm Value, (b) Profitability influences Firm Value, (c) Solvency influences Firm Value.

\section{METHODS}

The approach used was descriptive and verificative, which in this study sought to describe and also interpret the influence between the relationship of the variables to be examined and its purpose to present the picture in a structured, factual, and accurate about the facts of the relationship between the variables studied. 
The objects in this study were CSR Disclosure, Profitability, Solvency and Firm Valueof mining companies in ASEAN that were listed on the Stock Exchange of each country.

Operationalization of independent variables in this study were CSR Disclosure, Profitability, and Solvency, while Dependent Variable in this research was Firm Value. Operationalization of variables describe completely in Table 1.

Table 2. Sample Criteria

\begin{tabular}{lc}
\hline \multicolumn{1}{c}{ Population } & 57 \\
\hline $\begin{array}{l}\text { The Company publishes annual financial statements for } \\
\text { six consecutive years for from } 2009 \text { to } 2014\end{array}$ & \\
The Company publishes its CSR report for six & $(51)$ \\
consecutive years for from 2009 to 2014 & 6 \\
\hline Total Sample & \\
\hline Source: Data processed
\end{tabular}

The reason for choosing the sample by using purposive sampling is to get the sample based on the criteria specified. Determination of sample criteria required to avoid the occurrence of errors in the determination of research samples, which will further affect the results of the analysis (Table 2).

\section{RESULTS AND DISCUSSION}

The result of descriptive analysis for CSR Disclosure was that the average percentage owned by the six companies during the year 2009-2014 (6 years) was $34.10 \%$ of the total item of GRI G4 disclosure and the average CSR Disclosure was categorized as low criteria. This was because of the 6 companies studied were dominated by very low and low criteria.

The result of descriptive analysis for Profitability was that the average percentage owned by the six companies during the year 2009-2014 (6 years) was $7.43 \%$ of total equity and the average Profitability was categorized as low criteria. This was because all 6 companies studied had low criteria.

The result of descriptive analysis for Solvency was that the average percentage owned by the six companies during the year 2009-2014 (6 years) was $86.16 \%$ of total equity and the average Solvency was categorized as low criteria. This was because all 6 companies studied had low criteria.

The result of the descriptive analysis for Firm Value was that the average percentage owned by the six companies during the year 2009-2014 (6 years) was $169.60 \%$ and the average Firm Value was categorized as overvalued criteria, which means that the overall average of Firm Value was good. This was because the 6 companies studied were dominated by overvalued criteria.
Table 3. Multiple Linear Regression Analysis and t-Test

\begin{tabular}{|c|c|c|c|c|c|}
\hline \multicolumn{6}{|c|}{ Coefficients $^{\mathrm{a}}$} \\
\hline \multirow[b]{2}{*}{ Model } & \multicolumn{2}{|c|}{$\begin{array}{c}\text { Unstandardized } \\
\text { Coefficients }\end{array}$} & $\begin{array}{l}\text { Standardized } \\
\text { Coefficients }\end{array}$ & \multirow[b]{2}{*}{$\mathrm{t}$} & \multirow[b]{2}{*}{ Sig. } \\
\hline & B & $\begin{array}{l}\text { Std. } \\
\text { Error }\end{array}$ & Beta & & \\
\hline 1 (Constant) & .520 & .233 & & 2.233 & .033 \\
\hline CSR Disclosure & .021 & .020 & .171 & 1.060 & .298 \\
\hline Profitability & .426 & .295 & .240 & 1.446 & .159 \\
\hline Solvability & .295 & .156 & .328 & 1.887 & .069 \\
\hline
\end{tabular}

a. Dependent Variable: Firm Value

Based on Table 3, a multiple linear regression equation can be made as follows:

$$
\mathrm{Y}=0.520+0.021 \mathrm{X}_{1}+0.426 \mathrm{X}_{2}+0.295 \mathrm{X}_{3}
$$

From the regression equation above, it is shown that all of the independent variables have a positive coefficient which means that the better the CSR disclosure, profitability, and solvability of a company, the better the firm value of that company. On the contrary, if the CSR disclosure, profitability, and solvability were bad, the firm value of the company would also be bad.

Statistically, the result of regeression equation can be translated as below: (a) The constant value of 0.520 means if the company is not influenced by CSR disclosure, profitability, and solvability, then the market value of the company's capital will be $52.0 \%$ of the book value of the company. (b) The regression coefficient of CSR Disclosure is 0.021 , which means that every one percent of CSR disclosure disclosed by the company, it will raise the percentage of corporate value by $2.1 \%$. (c) The regression coefficient of Profitability is 0.426 , which means that every one percent increase in profitability, it will increase the percentage of corporate value by $42.6 \%$. (d) The regression coefficient of Solvability is 0.295 , which means that every one percent increase of solvency, it will increase the percentage of corporate value by $29.5 \%$.

We can also see on Table 3 for the result of t-test. This test will show whether independent variable has any significant effect on dependent variable. The value of ttable in this study is 2.035 from $t$ distribution table with $\alpha=5 \%$ and $\mathrm{df}=\mathrm{n}-\mathrm{k}-1 ; \mathrm{n}=36, \mathrm{k}=3$. The result can be explained as follows: (a) $t_{\text {coun }}$ t of CSR Disclosure is 1.060 and $t_{\text {table }}$ is 2.037. So $t_{\text {count }}<t_{\text {table }}$ which means that CSR Disclosure has no significant effect on Firm Value. (b) $t_{\text {count }}$ of Profitability is 1.446 and $t_{\text {table }}$ is 2.037. So $t_{\text {count }}<t_{\text {table }}$ which means that Profitability has no significant effect on Firm Value. (c) $t_{\text {count }}$ of Solvability is 1.887 and $t_{\text {table }}$ is 2.037. So $t_{\text {count }}$ $<\mathrm{t}_{\text {table }}$ which means that Solvability has no significant effect on Firm Value. 
Table 4. F-Test

\begin{tabular}{|c|c|c|c|c|c|c|}
\hline \multicolumn{7}{|c|}{ ANOVA $^{\mathrm{a}}$} \\
\hline \multicolumn{2}{|l|}{ Model } & $\begin{array}{l}\text { Sum of } \\
\text { Squares }\end{array}$ & df & $\begin{array}{l}\text { Mean } \\
\text { Square }\end{array}$ & $\mathrm{F}$ & Sig. \\
\hline \multirow[t]{3}{*}{1} & Regression & 1.102 & 3 & .367 & 4.062 & $.016^{\mathrm{b}}$ \\
\hline & Residual & 2.713 & 30 & .090 & & \\
\hline & Total & 3.815 & 33 & & & \\
\hline
\end{tabular}

a. Dependent Variable: Firm Value

b. Predictors: (Constant), Solvability, CSR Disclosure, Profitability

Above is the result of F-test using SPSS. The value of $F_{\text {count }}$ is 4.062 with Sig. of 0.016 . The value of $F_{\text {table }}$ in this study is 2.090 from $\mathrm{F}$ distribution table with $\alpha=$ $5 \%$ and $\mathrm{df}_{1}=\mathrm{k}$ and $\mathrm{df}_{2}=\mathrm{n}-\mathrm{k}-1 ; \mathrm{n}=36, \mathrm{k}=3$. So $\mathrm{F}_{\text {count }}$ $>F_{\text {table }}$ which means that CSR Disclosure, Profitability, and Solvability simultaneously have signisficant effect on Firm Value.

Table 5. Partial Pearson Correlation Analysis

\begin{tabular}{llr}
\multicolumn{3}{c}{ Correlations } \\
\hline \multirow{5}{*}{ CSR Disclosure } & Pearson Correlation & Firm Value \\
& Sig. (2-tailed) & .295 \\
& $\mathrm{~N}$ & .081 \\
\multirow{5}{*}{ Profitability } & 36 \\
& Pearson Correlation & $.369^{*}$ \\
& Sig. (2-tailed) & .032 \\
& $\mathrm{~N}$ & 34 \\
& Pearson Correlation & $.417^{*}$ \\
& Sig. (2-tailed) & .011 \\
& $\mathrm{~N}$ & 36 \\
\hline *. Correlation is significant at the 0.05 level (2-tailed). &
\end{tabular}

Based on Table 5, we can see the the pearson correlation value of each independent variables towards the dependent variable. This test will interpret the relation strength between independent variable with the dependent variable. Here are the explanations: (a) The correlation value of CSR Disclosure towards Firm Value is 0.295 , which means that CSR Disclosure has a weak relation with Firm Value. (b) The correlation value of Profitability towards Firm Value is 0.369 , which means that Profitability has a moderate relation with Firm Value. (c) The correlation value of Solvability towards Firm Value is 0.417 , which means that Solvability has a moderate relation with Firm Value.

In table 6 below shows the the multiple pearson correlation value (R) between CSR Disclosure, Profitability, Solvability towards Firm Value, which is 0.537 . This means that CSR Disclosure, Profitability, Solvability simultaneously have a strong relation with Firm Value.
Table 6. Coefficient of Determination

\begin{tabular}{lcccc}
\multicolumn{5}{c}{ Model Summary $^{\mathrm{b}}$} \\
\hline Model & $\mathrm{R}$ & $\mathrm{R}$ & $\begin{array}{c}\text { Adjusted R } \\
\text { Square }\end{array}$ & $\begin{array}{c}\text { Std. Error of } \\
\text { the Estimate }\end{array}$ \\
\hline 1 & $.537^{\mathrm{a}}$ & .289 & .218 & .30073 \\
\hline a. Predictors: (Constant), Solvability, CSR Disclosure, Profitability \\
b. Dependent Variable: Firm Value
\end{tabular}

Table 6 shows the value of R Square or coefficient of determination is 0.289 . The value of 0.289 or equal to $28.9 \%$ indicates CSR Disclosure, Profitability, and Solvability simultaneously give a contribution of $28.9 \%$ towards Firm Value. While the rest that is $71.1 \%$ explained/influenced by factors outside this model.

\section{CONCLUSION}

The average level of CSR Dislcosure of mining companies is low. Companies need to disclose more corporate social responsibility to more investors investing in companies. The average level of CSR Dislcosure of mining companies is low too. Companies need to manage the funds owned better so that the maximum profit can be generated. Average Solvency rates of mining companies fall under the low criteria. The company should lower the loan lending because the large composition of debt rather than the capital itself causes the risk of the company unable to pay the debt and relatively difficult to request additional credit for financing.

\section{REFERENCES}

Agustina, Silvia. 2013. Pengaruh Profitabilitas dan Pengungkapan Corporate Social Responsibility terhadap Nilai Perusahaan (Studi Empiris pada Perusahaan Manufaktur yang terdaftar di Bursa Efek Indonesia), Universitas Negeri Padang. http://ejournal. unp.ac.id/students/index.php/akt/article/view/71

Amelia, Mega Rizki. 2013. Effect of Firm Caharacteristics, Financial Performance and Environmental Performance on Corporate Social Responsibility Disclosure Intensity of Manufacturing Firms Listed in the Indonesia Stock Exchange. https://www.academia.edu/6780747

Brigham, Eugene F. dan Joul F. Houston. 2011. Dasar dasar Manajemen Keuangan. Jakarta: Salemba Empat.

Disfiyant Glienmourinsie. 2016. BPS Ramal Sektor Tambang Kuartal II Masih Lemah. Available at: https:/lekbis.sindonews.com/read/1106165/34/ bps-ramal-sektor-tambang-kuartal-ii-masihlemah-1462352048 (Accessed: 12 March 2018).

Fakhruddin , Hendy M. 2008. Istilah Pasar Modal A - Z. Jakarta: PT Elex Media Komputindo.

Harahap, S. S. 2013. Analisis Kritis Atas Laporan Keuangan (Cetakan Kesebelas). Jakarta: Rajawali Pers. 
Kamil, Ahmad dan Herusetya, Antonius. 2012. Pengaruh Karakteristik Perusahaan terhadap Luas Pengungkapan Kegiatan Corporate Social Responsibility. Media Riset Akuntansi, Vol. 2, No. 1, Februari 2012, hal. 1-17.

Kasmir. 2012. Analisis Laporan Keuangan. Jakarta: Raja Grafindo.

Keown, Arthur J. et. al. 2010. Manajemen Keuangan: Principles and Applications, Tenth Edition. Jakarta: PT INDEKS

Kusumadilaga, Rimba. 2010. Pengaruh CSR terhadap Nilai Perusahaan dengan Profitabilitas sebagai Variabel Moderating pada Perusahaan Manufaktur yang Terdaftar di BEI tahun 2006 dan 2008. http:// eprints.undip.ac.id/22572/

Risa Herdahita Putri. 2015. Perlambatan Ekonomi Pukul Saham Sektor Pertambangan. Available at: https:// republika.co.id/berita/ekonomi/keuangan/15/08/06/ nsnqv9349-perlambatan-ekonomi-pukul-sahamsektor-pertambangan (Accessed: 12 March 2018).
Sukirni, Dwi. 2012. Kepemilikan Manajerial, Kepemilikan Institusional, Kebijakan Deviden dan Kebijakan Hutang Analisis Terhadap Nilai Perusahaan. https://journal.unnes.ac.id/sju/index. php/aaj/article/view/703

Susanti, Rika. 2010. Analisis Faktor-Faktor Yang Berpengaruh Terhadap Nilai Perusahaan pada Perusahaan Go Public yang Listed Tahun 20052008. http://eprints.undip.ac.id/23439/

White, H. 2002. Businesses Mobilize Production through Markets: Parametric Modeling of Pathdependent Outcomes in Oriented Network Flows, Complexity 8(1): 87-95

Yuniasih, Ni Wayan dan Wirakusuma, Made Gede. 2007. Pengaruh Kinerja Keuangan terhadap Nilai Perusahaan dengan Pengungkapan Corporate Social Responsibility dan Good Corporate Governance sebagai Variabel Pemoderasi. http:// id.portalgaruda.org/?ref=browse\&mod=viewarti cle\&article $=14043$

Table 1. Operationalization of Variables

\begin{tabular}{llcl}
\hline \multicolumn{3}{c}{ Independent Variable } & \\
\hline Variable & \multicolumn{1}{c}{ Variable Concept } & Indicator & Scale \\
\hline CSR & Disclosure of corporate social responsibility which is & Ratio \\
Disclosure & often also referred to as social disclosure, corporate social & CSRDI $_{\mathrm{j}}=\frac{\sum \mathrm{X}_{\mathrm{j}}}{\mathrm{n}_{\mathrm{j}}} \times 100 \%$ & \\
$\left(\mathrm{X}_{1}\right)$ & reporting, social accounting (Mathews, 1995) or the & &
\end{tabular}
corporate social responsibility (Hackston and Milne, 1996) is a process of communicating the social and environmental impact of economic activities of the organization with respect to specific groups of interested parties and to society as a whole. (Amelia, 2013)

Haniffa et al (2005) in Agustina (2013) adjusted

$$
\begin{array}{ll}
\text { CSRDI }_{\mathrm{j}} & : \text { Corporate Social Responsibility Disclosure } \\
& \text { Index of } \mathrm{j} \text { company } \\
\mathrm{X}_{\mathrm{j}} & : \text { Total disclosed item of } \mathrm{j} \text { company } \\
\mathrm{n}_{\mathrm{j}} & : \text { Total disclosure item }
\end{array}
$$

Profitability The level of net profit that can be achieved by the company $\left(\mathrm{X}_{2}\right) \quad$ when running its operations. Profitability describes the company's revenue to finance the investment. Profitability demonstrates the ability of the capital invested in the overall assets to generate profits for investors. (Kusumadilaga, 2010)

$$
\mathrm{ROE}=\frac{\text { Earning after Taxes }}{\text { Total Equity }} \times 100 \%
$$

Ratio

(Kasmir, 2012:204)

$$
\mathrm{DER}=\frac{\text { Total Liabilities }}{\text { Total Equity }} \times 100 \%
$$

Ratio

Solvabilitas Leverage is the amount of debt used to finance/ buy company assets. Companies that have a larger debt than equity are said to be companies with high leverage levels. (Fakhrudin, 2008:109)

(Kasmir, 2012:166)

Dependent Variable

Firm Value The value of the firm is the market value of the firm's debt (Y) and equity.

(Keown, et. al., 2010:35)

$$
q=\frac{(E M S+D)}{(E B V+D)} \times 100 \%
$$

White, et. al. (2002)

EMV : Equity Market Value

EBV : Equity Book Value

D : Liabilities Book Value 